\title{
Paracoccus fistulariae sp. nov., a lipolytic bacterium isolated from bluespotted cornetfish, Fistularia commersonii
}

Correspondence

Jung-Hoon Yoon

jhyoon@kribb.re.kr
Young-Ok Kim, ${ }^{1}$ Hee Jeong Kong, ${ }^{1}$ Sooyeon Park, ${ }^{2}$ So-Jung Kang, ${ }^{2}$
Kyung-Kil Kim, ${ }^{1}$ Dae Yeon Moon, ${ }^{3}$ Tae-Kwang $\mathrm{Oh}^{2}$ and Jung-Hoon Yoon ${ }^{2}$

\author{
${ }^{1}$ Biotechnology Research Division, National Fisheries Research and Development Institute, Gijang, \\ Busan 619-705, Republic of Korea \\ ${ }^{2}$ Korea Research Institute of Bioscience and Biotechnology, PO Box 115, Yusong, Taejon, Republic \\ of Korea \\ ${ }^{3}$ Fisheries Resources Research Division, National Fisheries Research and Development Institute, \\ Gijang, Busan 619-705, Republic of Korea
}

A Gram-stain-negative, non-motile, non-spore-forming and short rod- or rod-shaped bacterial strain, designated $22-5^{\top}$, was isolated from a bluespotted cornetfish, Fistularia commersonii, and subjected to taxonomic study. Strain $22-5^{\top}$ grew optimally at $30{ }^{\circ} \mathrm{C}$ and in the presence of $2-5 \%$ $(\mathrm{w} / \mathrm{v}) \mathrm{NaCl}$. Phylogenetic analyses based on $16 \mathrm{~S}$ rRNA gene sequences revealed that strain 22$5^{\top}$ belonged to the genus Paracoccus and joined the cluster comprising Paracoccus homiensis DD-R $11^{\top}$ and Paracoccus zeaxanthinifaciens ATCC $21588^{\top}$, with which strain $22-5^{\top}$ exhibited 97.4 and $96.9 \%$ 16S rRNA gene sequence similarity, respectively. Strain $22-5^{\top}$ exhibited 94.0$96.6 \% 16 S$ rRNA gene sequence similarity with the other type strains of species of the genus Paracoccus. Strain $22-5^{\top}$ contained $\mathrm{Q}-10$ as the predominant menaquinone and $\mathrm{C}_{18: 1} \omega 7 \mathrm{c}$ as the predominant fatty acid. In this study, $P$. zeaxanthinifaciens $\mathrm{KCTC}_{22688^{\top}}$ also contained $\mathrm{Q}$ 10 as the predominant isoprenoid quinone. The DNA G+C content of strain $22-5^{\top}$ was 63.6 mol\%. Strain $22-5^{\top}$ exhibited 44 and $32 \%$ DNA-DNA relatedness to $P$. homiensis KACC $11518^{\top}$ and $P$. zeaxanthinifaciens KCTC $22688^{\top}$, respectively. On the basis of phenotypic, phylogenetic and genetic data, strain $22-5^{\top}$ is considered to represent a novel species of the genus Paracoccus, for which the name Paracoccus fistulariae sp. nov. is proposed. The type strain is $22-5^{\top}\left(=\right.$ KCTC $22803^{\top}=$ CCUG $\left.58401^{\top}\right)$.
The genus Paracoccus was first described by Davis et al. (1969) to accommodate a Gram-negative, catalase- and oxidase-positive, coccoid-shaped bacterium, Paracoccus denitrificans. Subsequently, at least 26 species with validly published names have been proposed as members of the genus Paracoccus (Euzéby, 2009). Phylogenetic analyses based on 16S rRNA gene sequences have shown that the genus Paracoccus falls within the class Alphaproteobacteria (Anzai et al., 2000; Lee et al., 2005). Members of the genus Paracoccus are chemotaxonomically characterized as having ubiquinone-10 as the predominant isoprenoid quinone and $\mathrm{C}_{18: 1}$ as the major fatty acid (Kelly et al., 2006; Roh et al., 2009). Early described species of the genus Paracoccus were isolated from various terrestrial environments (Kelly et al., 2006) and some recently described species have been isolated from marine environments, including intertidal sediment and seawater (Khan et al.,

The GenBank/EMBL/DDBJ accession number for the 16S rRNA gene sequence of strain $22-5^{\top}$ is GQ260189.
2008; Kim et al., 2006; Lee et al., 2004; Liu et al., 2008; Pukall et al., 2003; Roh et al., 2009). In this study, we describe a Paracoccus-like bacterial strain, 22-5 ${ }^{\mathrm{T}}$, which was isolated from the intestine of a bluespotted cornetfish, Fistularia commersonii.

Strain $22-5^{\mathrm{T}}$ was isolated by means of the standard dilution-plating technique on marine agar 2216 (MA; Difco) at $25{ }^{\circ} \mathrm{C}$. The type strains of Paracoccus homiensis and Paracoccus zeaxanthinifaciens were used as reference strains for phenotypic characterization, fatty acid analysis and DNA-DNA hybridization: $P$. homiensis KACC $11518^{\mathrm{T}}$ was obtained from the Korean Agricultural Culture Collection and P. zeaxanthinifaciens KCTC $22688^{\mathrm{T}}$ was obtained from the Korean Collection for Type Cultures. For DNA and isoprenoid quinone extraction, cultures were prepared in marine broth 2216 (MB; Difco) at $30{ }^{\circ} \mathrm{C}$ for 3 days. For fatty acid extraction and morphological, physiological and biochemical characterization, cultures were prepared on MA at $30{ }^{\circ} \mathrm{C}$ for 3 days. 
Table 1. Differential phenotypic characteristics of strain $22-5^{\top}$ and the type strains of the two most closely related species of the genus Paracoccus

Strains: 1 , Paracoccus fistulariae sp. nov. $22-5^{\mathrm{T}} ; 2$, P. homiensis KACC $11518^{\mathrm{T}} ; 3$, P. zeaxanthinifaciens KCTC $22688^{\mathrm{T}}$. All data from this study unless otherwise indicated. All strains were Gram-negative, rod-shaped and positive for catalase ${ }^{\star}$, oxidase $e^{\star}$, hydrolysis of tyrosine, Tweens 20 and 40 and hypoxanthine, utilization of cellobiose, D-fructose, Dgalactose, D-glucose, maltose, D-mannose, sucrose, acetate, citrate, Lmalate, pyruvate and succinate, activity of alkaline phosphatase, esterase (C4) and $\alpha$-glucosidase and susceptibility to carbenicillin, cephalothin, chloramphenicol, gentamicin, kanamycin, neomycin, polymyxin B and streptomycin. All strains were negative for production of $\mathrm{H}_{2} \mathrm{~S}$ and indole, hydrolysis of casein, starch and urea, utilization of benzoate, formate and L-glutamate, acid production from D-mannitol, melezitose, raffinose and trehalose, activity of lipase (C14), arginine dihydrolase, lysine decarboxylase, ornithine decarboxylase, tryptophan deaminase, valine arylamidase, trypsin, $\alpha$-chymotrypsin, $\alpha$ fucosidase, $\beta$-glucuronidase, $\beta$-glucosidase, $N$-acetyl- $\beta$-glucosaminidase and $\alpha$-mannosidase and susceptibility to lincomycin and oleandomycin. +, Positive; w, weakly positive; -, negative.

\begin{tabular}{|c|c|c|c|}
\hline Characteristic & 1 & 2 & 3 \\
\hline Motility & - & $+^{*}$ & $-{ }^{\star}$ \\
\hline $\mathrm{NaCl}$ range for growth (\%) & $0-14 \dagger$ & $0-14^{*}$ & $3-8^{*}$ \\
\hline Nitrate reduction & + & $-{ }^{*}$ & $-{ }^{*}$ \\
\hline Lipolytic activity & + & - & - \\
\hline \multicolumn{4}{|l|}{ Hydrolysis of: } \\
\hline Aesculin & + & - & + \\
\hline Gelatin & + & + & - \\
\hline Tween 60 & + & - & + \\
\hline Tween 80 & + & - & + \\
\hline Xanthine & + & + & - \\
\hline \multicolumn{4}{|l|}{ Utilization of: } \\
\hline L-Arabinose & + & - & - \\
\hline Salicin & + & - & - \\
\hline Trehalose & + & - & - \\
\hline D-Xylose & - & + & - \\
\hline \multicolumn{4}{|l|}{ Acid production from: } \\
\hline L-Arabinose & + & + & $\mathrm{W}$ \\
\hline Cellobiose & + & - & - \\
\hline D-Fructose & + & - & + \\
\hline D-Galactose & + & - & + \\
\hline D-Glucose & + & - & + \\
\hline myo-Inositol & - & + & + \\
\hline Lactose & + & - & - \\
\hline Maltose & + & $\mathrm{w}$ & + \\
\hline D-Mannose & + & - & + \\
\hline Melibiose & + & - & $\mathrm{w}$ \\
\hline L-Rhamnose & + & + & - \\
\hline D-Ribose & + & - & + \\
\hline D-Sorbitol & - & W & - \\
\hline Sucrose & + & - & + \\
\hline D-Xylose & + & + & - \\
\hline \multicolumn{4}{|l|}{ Enzyme activity (API ZYM) } \\
\hline Acid phosphatase & w & + & - \\
\hline Esterase lipase (C8) & - & + & - \\
\hline Leucine arylamidase & $\mathrm{W}$ & + & $\mathrm{W}$ \\
\hline
\end{tabular}

Table 1. cont.

\begin{tabular}{|lccc|}
\hline Characteristic & $\mathbf{1}$ & $\mathbf{2}$ & $\mathbf{3}$ \\
\hline Cystine arylamidase & - & + & - \\
Naphthol-AS-BI- & $\mathrm{W}$ & + & - \\
phosphohydrolase & & & \\
$\alpha$-Galactosidase & - & + & + \\
$\beta$-Galactosidase & - & + & + \\
Susceptibility to: & & & \\
Ampicillin & + & - & - \\
Novobiocin & + & + & - \\
Penicillin G & + & + & - \\
Tetracycline & + & - & - \\
DNA G+C (mol\%) & 63.6 & $63^{\star}$ & $66.9-67.7^{\star}$ \\
\hline
\end{tabular}

${ }^{\star}$ Data were taken from Kim et al. (2006) and Berry et al. (2003) for columns 2 and 3, respectively.

$\dagger$ Growth with $0 \% \mathrm{NaCl}$ occurs when $\mathrm{Mg}^{2+}$ ions are added.

Cell morphology was examined by light microscopy (Nikon E600) and transmission electron microscopy. Flagellation was determined by using a Philips CM-20 transmission electron microscope with cells from an exponentially growing culture. For this purpose, the cells were negatively stained with $1 \%(\mathrm{w} / \mathrm{v})$ phosphotungstic acid and the grids were examined after being air-dried. The Gram reaction was determined by using a Gram-stain kit (bioMérieux), according to the manufacturer's instructions. Growth at $4,10,20,25,28,30,35,37,40$ and $45^{\circ} \mathrm{C}$ was determined on MA. Growth with $0,0.5,1.0,2.0$ and $3.0 \%(\mathrm{w} / \mathrm{v}) \mathrm{NaCl}$ was investigated in trypticase soy broth prepared according to the formula of the Difco medium except for the exclusion of $\mathrm{NaCl}$ and inclusion of $0.45 \%$ (w/v) $\mathrm{MgCl}_{2} \cdot 6 \mathrm{H}_{2} \mathrm{O}$ or $0.06 \%$ (w/v) KCl. Growth with $2.0-$ $15.0 \%(\mathrm{w} / \mathrm{v}) \mathrm{NaCl}$ (in increments of $1.0 \%$ ) was investigated in $\mathrm{MB}$. The $\mathrm{pH}$ range for growth was determined in $\mathrm{MB}$ adjusted to $\mathrm{pH} 4.5-9.5$ (in increments of $0.5 \mathrm{pH}$ unit) with sodium acetate/acetic acid and $\mathrm{Na}_{2} \mathrm{CO}_{3}$ buffers. Growth under anaerobic conditions was determined after incubation in a Forma anaerobic chamber on MA and on MA supplemented with potassium nitrate $(0.1 \%, \mathrm{w} / \mathrm{v})$, both prepared anaerobically under a nitrogen atmosphere. Catalase and oxidase activities were determined as described by Cowan \& Steel (1965). Lipolytic activity was investigated on tricaprylin-MA, which was prepared as follows: $5 \mathrm{ml}$ tricaprylin was emulsified in $45 \mathrm{ml}$ gum arabic solution $\left(200 \mathrm{mM} \mathrm{NaCl}, 10 \mathrm{mM} \mathrm{CaCl}_{2}\right.$ and $5 \%$, w/v, gum arabic) for $2 \mathrm{~min}$ using a Waring blender and $50 \mathrm{ml}$ tricaprylin emulsion was mixed with $450 \mathrm{ml}$ MA. Hydrolysis of casein, starch, hypoxanthine, tyrosine and xanthine was tested on MA using the substrate concentrations described by Cowan \& Steel (1965). Nitrate reduction and hydrolysis of aesculin, gelatin, urea and Tweens 20, 40, 60 and 80 were investigated as described by Lanyí (1987) with the modification that artificial seawater was used for preparation of media. The artificial seawater contained $\left(1^{-1}\right.$ distilled water) $23.6 \mathrm{~g} \mathrm{NaCl}, 0.64 \mathrm{~g} \mathrm{KCl}, 4.53 \mathrm{~g} \mathrm{MgCl}_{2} .6 \mathrm{H}_{2} \mathrm{O}, 5.94 \mathrm{~g}$ 
$\mathrm{MgSO}_{4} \cdot 7 \mathrm{H}_{2} \mathrm{O}$ and $1.3 \mathrm{~g} \mathrm{CaCl}_{2} \cdot 2 \mathrm{H}_{2} \mathrm{O}$ (Bruns et al., 2001). $\mathrm{H}_{2} \mathrm{~S}$ production was tested as described by Bruns et al. (2001). Acid production from carbohydrates was determined as described by Leifson (1963). Utilization of substrates as sole carbon and energy sources was tested as described by Baumann \& Baumann (1981) using supplementation with $2 \%(\mathrm{v} / \mathrm{v})$ Hutner's mineral base (Cohen-Bazire et al., 1957) and $1 \%(\mathrm{v} / \mathrm{v})$ vitamin solution (Staley, 1968). Susceptibility to antibiotics was tested on MA plates using antibiotic discs containing the following ( $\mu \mathrm{g}$ per disc unless otherwise stated): polymyxin $B(100 \mathrm{U})$, streptomycin (50), penicillin $\mathrm{G}(20 \mathrm{U})$, chloramphenicol (100), ampicillin (10), cephalothin (30), gentamicin (30), novobiocin (5), tetracycline (30), kanamycin (30), lincomycin (15), oleandomycin (15), neomycin (30) and carbenicillin (100). Other physiological and biochemical tests were performed with the API 20E and API ZYM systems (bioMérieux). The morphological, cultural, physiological and biochemical characteristics of strain $22-5^{\mathrm{T}}$ are given in the species description and Table 1.

Chromosomal DNA was isolated and purified according to the method described previously (Yoon et al., 1996), with the exception that RNase T1 was used in combination with RNase A to minimize contamination with RNA. The 16S rRNA gene was amplified by PCR using two universal primers as described previously (Yoon et al., 1998). Sequencing of the amplification products and phylogenetic analysis were performed as described previously (Yoon et al., 2003). The identification of phylogenetic neighbours was achieved using the EzTaxon server (http://www. eztaxon.org/; Chun et al., 2007). The almost-complete
$16 \mathrm{~S}$ rRNA gene sequence of strain $22-5^{\mathrm{T}}$ determined in this study comprised $1383 \mathrm{nt}$. In the neighbour-joining phylogenetic tree based on $16 \mathrm{~S}$ rRNA gene sequences, strain 22$5^{\mathrm{T}}$ fell within the clade comprising species of the genus Paracoccus and formed a coherent cluster with $P$. homiensis DD-R $11^{\mathrm{T}}$ and P. zeaxanthinifaciens ATCC $21588^{\mathrm{T}}$ (Fig. 1). The same cluster was found in the trees reconstructed using the maximum-likelihood and maximum-parsimony algorithms (Fig. 1). Strain $22-5^{\mathrm{T}}$ exhibited 97.4 and $96.6 \% 16 \mathrm{~S}$ rRNA gene sequence similarity with $P$. homiensis DD-R $11^{\mathrm{T}}$ and $P$. zeaxanthinifaciens ATCC $21588^{\mathrm{T}}$, respectively, and $94.0-96.6 \%$ with the type strains of the other species of the genus Paracoccus. The DNA G $+\mathrm{C}$ content was determined by the method of Tamaoka \& Komagata (1984) with the modification that DNA was hydrolysed and the resultant nucleotides were analysed by reversed-phase HPLC. The DNA G $+\mathrm{C}$ content of strain $22-5^{\mathrm{T}}$ was $63.6 \mathrm{~mol} \%$.

Isoprenoid quinones were extracted according to the method of Komagata \& Suzuki (1987) and analysed using reversed-phase HPLC and a YMC ODS-A $(250 \times 4.6 \mathrm{~mm})$ column. The predominant isoprenoid quinone detected in strain $22-5^{\mathrm{T}}$ was ubiquinone-10 (Q-10), which was in line with those for other members of the genus Paracoccus (Kelly et al., 2006; Roh et al., 2009). In this study, P. zeaxanthinifaciens $\mathrm{KCTC} 22688^{\mathrm{T}}$ was also found to have Q10 as the predominant isoprenoid quinone. The fatty acid methyl esters were extracted and prepared according to the standard protocol of the Hewlett Packard Microbial Identification System (MIDI; Sasser, 1990). The fatty acid profile of strain $22-5^{\mathrm{T}}$ is shown in Table 2 with those of

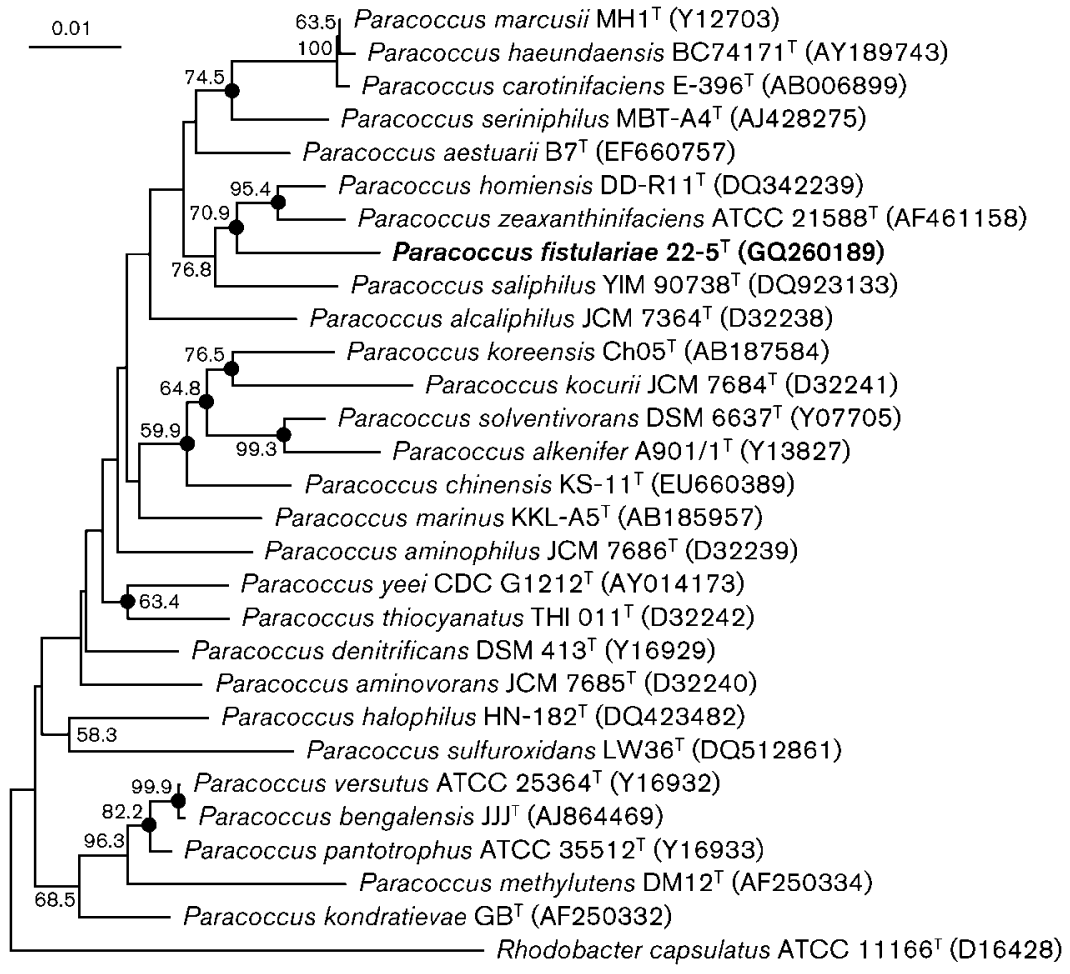

Fig. 1. Neighbour-joining phylogenetic tree based on 16S rRNA gene sequences showing the positions of strain $22-5^{\top}$ and members of the genus Paracoccus. Bootstrap values $(>50 \%)$ based on 1000 replications are shown at branch nodes. Filled circles indicate that the corresponding nodes were also recovered in the trees generated with the maximum-likelihood and maximum-parsimony algorithms. Rhodobacter capsulatus ATCC $11166^{\top}$ was used as an outgroup. Bar, 0.01 substitutions per nucleotide position. 
Table 2. Cellular fatty acid compositions of strain $22-5^{\top}$ and the type strains of the two most closely related species of the genus Paracoccus

Strains: 1 , Paracoccus fistulariae sp. nov. $22-5^{\mathrm{T}} ; 2$, P. homiensis KACC $11518^{\mathrm{T}}$; 3, P. zeaxanthinifaciens KCTC $22688^{\mathrm{T}}$. All data from this study. Fatty acids that represented $<0.5 \%$ in all strains are omitted. ECL, Equivalent chain-length.

\begin{tabular}{|lccc|}
\hline Fatty acid (\%) & $\mathbf{1}$ & $\mathbf{2}$ & $\mathbf{3}$ \\
\hline Straight-chain & & & \\
$\quad \mathrm{C}_{16: 0}$ & 0.7 & 0.6 & 0.4 \\
$\mathrm{C}_{18: 0}$ & 10.1 & 6.5 & 4.5 \\
Unsaturated & & & \\
$\quad \mathrm{C}_{17: 1} \omega 7 c$ & 0.3 & 1.1 & 0.7 \\
$\mathrm{C}_{18: 1} \omega 7 c$ & 73.8 & 72.1 & 82.9 \\
Hydroxy & & & \\
$\quad \mathrm{C}_{11: 0} 2-\mathrm{OH}$ & 3.1 & 3.1 & 3.5 \\
$\mathrm{C}_{12: 0} 3-\mathrm{OH}$ & 0.6 & 0.5 & 0.6 \\
$11-\mathrm{Methyl} \mathrm{C}_{18: 1} \omega 7 c$ & 3.6 & 10.2 & - \\
Summed feature 2* & 3.5 & 2.0 & 3.2 \\
ECL 11.799 & 2.9 & 2.9 & 3.3 \\
\hline
\end{tabular}

${ }^{*}$ Summed features represent two or three fatty acids that cannot be separated by the Microbial Identification System. Summed feature 2 consisted of iso- $\mathrm{C}_{16: 1}$ and/or $\mathrm{C}_{14: 0} 3-\mathrm{OH}$.

P. homiensis KACC $11518^{\mathrm{T}}$ and P. zeaxanthinifaciens KCTC $22688^{\mathrm{T}}$ also analysed in this study. Strain $22-5^{\mathrm{T}}$ contained large amounts of unsaturated, straight-chain, hydroxy and 11 -methyl fatty acids; the major components $(>10 \%$ of total fatty acids) were $\mathrm{C}_{18: 1} \omega 7 \mathrm{c}$ and $\mathrm{C}_{18: 0}$. The fatty acid profiles of strain $22-5^{\mathrm{T}}, P$. homiensis KACC $11518^{\mathrm{T}}$ and $P$. zeaxanthinifaciens KCTC $22688^{\mathrm{T}}$ were essentially similar in that $\mathrm{C}_{18: 1} \omega 7 c$ was the predominant fatty acid, although there were differences in the proportions of some fatty acids. The results obtained from chemotaxonomic analyses confirmed the result of phylogenetic analysis, i.e. that strain $22-5^{\mathrm{T}}$ belongs to the genus Paracoccus (Kelly et al., 2006; Roh et al., 2009; Tables 1 and 2).

DNA-DNA hybridization was performed fluorometrically by the method of Ezaki et al. (1989) using photobiotinlabelled DNA probes and microdilution wells. Hybridization was performed with five replications for each sample. The highest and lowest values obtained for each sample were excluded and the means of the remaining three values were quoted as DNA-DNA relatedness values. Strain $22-5^{\mathrm{T}}$ exhibited 44 and $32 \%$ mean DNA-DNA relatedness with $P$. homiensis KACC $11518^{\mathrm{T}}$ and P. zeaxanthinifaciens KCTC $22688^{\mathrm{T}}$, respectively, which indicated that it differed genetically from the two reference strains (Wayne et al., 1987).

Strain $22-5^{\mathrm{T}}$ was distinguishable from the two reference strains by differences in several phenotypic characteristics, most of which were determined in this study using the same conditions and methods (Table 1). The phylogenetic and genetic distinctiveness and the phenotypic properties of strain $22-5^{\mathrm{T}}$ are sufficient to show that this strain is separate from recognized species of the genus Paracoccus (Stackebrandt \& Goebel, 1994). Therefore, strain $22-5^{\mathrm{T}}$ is considered to represent a novel species of the genus Paracoccus, for which the name Paracoccus fistulariae sp. nov. is proposed.

\section{Description of Paracoccus fistulariae sp. nov.}

Paracoccus fistulariae (fi.stu.la'ri.ae. N.L. gen. n. fistulariae of Fistularia, named after the generic name of the bluespotted cornetfish, Fistularia commersonii, from which the type strain was isolated).

Cells are Gram-stain-negative, non-spore-forming, nonflagellated, short rods or rods $(0.3-0.6 \times 0.7-2.5 \mu \mathrm{m})$. Colonies on MA after 3 days at $30{ }^{\circ} \mathrm{C}$ are circular, slightly convex, smooth, glistening, greyish-yellow and $2.0-3.0 \mathrm{~mm}$ in diameter. Grows at $10-40{ }^{\circ} \mathrm{C}$ (optimum $30{ }^{\circ} \mathrm{C}$ ), but not at 4 or $45{ }^{\circ} \mathrm{C}$. Grows at pH 5.0 (optimum pH 7.0-8.0), but not at $\mathrm{pH}$ 4.5. Grows with $0-14.0 \%$ (w/v) $\mathrm{NaCl}$ (optimum $2-5 \% \mathrm{NaCl}) . \mathrm{Mg}^{2+}$ ions are required for growth. Growth does not occur under anaerobic conditions on MA or on MA supplemented with nitrate. Catalase- and oxidasepositive. Nitrate reduction is positive. Shows lipolytic activity. The predominant ubiquinone is Q-10. The major fatty acids (>10\% of total fatty acids) are $\mathrm{C}_{18: 1} \omega 7 c$ and $\mathrm{C}_{18: 0}$. Other phenotypic properties are shown in Table 1. The DNA G + C content of the type strain is $63.6 \mathrm{~mol} \%$ (HPLC).

The type strain, $22-5^{\mathrm{T}}\left(=\right.$ KCTC $22803^{\mathrm{T}}=$ CCUG $\left.58401^{\mathrm{T}}\right)$, was isolated from the intestine of the bluespotted cornetfish, Fistularia commersonii.

\section{Acknowledgements}

This work was supported by a grant from the National Fisheries Research and Development Institute and the 21C Frontier Program of Microbial Genomics and Applications (grant no. MG05-0401-2-0) from the Ministry of Education, Science and Technology of the Republic of Korea.

\section{References}

Anzai, Y., Kim, H., Park, J.-Y., Wakabayashi, H. \& Oyaizu, H. (2000). Phylogenetic affiliation of the pseudomonads based on 16S rRNA sequence. Int J Syst Evol Microbiol 50, 1563-1589.

Baumann, P. \& Baumann, L. (1981). The marine Gram-negative eubacteria: genera Photobacterium, Beneckea, Alteromonas, Pseudomonas, and Alcaligenes. In The Prokaryotes, pp. 1302-1331. Edited by M. P. Starr, H. Stolp, H. G. Trüper, A. Balows \& H. G. Schlegel. Berlin: Springer-Verlag.

Berry, A., Janssens, D., Hümbelin, M., Jore, J. P. M., Hoste, B., Cleenwerck, I., Vancanneyt, M., Bretzel, W., Mayer, A. F. \& other authors (2003). Paracoccus zeaxanthinifaciens sp. nov., a zeaxanthinproducing bacterium. Int J Syst Evol Microbiol 53, 231-238.

Bruns, A., Rohde, M. \& Berthe-Corti, L. (2001). Muricauda ruestringensis gen. nov., sp. nov., a facultatively anaerobic, appendaged 
bacterium from German North Sea intertidal sediment. Int J Syst Evol Microbiol 51, 1997-2006.

Chun, J., Lee, J.-H., Jung, Y., Kim, M., Kim, S., Kim, B. K. \& Lim, Y.-W. (2007). EzTaxon: a web-based tool for the identification of prokaryotes based on 16 S ribosomal RNA gene sequences. Int J Syst Evol Microbiol 57, 2259-2261.

Cohen-Bazire, G., Sistrom, W. R. \& Stanier, R. Y. (1957). Kinetic studies of pigment synthesis by non-sulfur purple bacteria. J Cell Physiol 49, 25-68.

Cowan, S. T. \& Steel, K. J. (1965). Manual for the Identification of Medical Bacteria. London: Cambridge University Press.

Davis, D. H., Doudoroff, M., Stanier, R. Y. \& Mandel, M. (1969). Proposal to reject the genus Hydrogenomonas: taxonomic implications. Int J Syst Bacteriol 19, 375-390.

Euzéby, J. P. (2009). List of bacterial names with standing in nomenclature: a folder available on the Internet. [Last full update 6 February 2009]. http://www.bacterio.net

Ezaki, T., Hashimoto, Y. \& Yabuuchi, E. (1989). Fluorometric deoxyribonucleic acid-deoxyribonucleic acid hybridization in microdilution wells as an alternative to membrane filter hybridization in which radioisotopes are used to determine genetic relatedness among bacterial strains. Int J Syst Bacteriol 39, 224-229.

Kelly, D. P., Rainey, F. A. \& Wood, A. P. (2006). The genus Paracoccus. In The Prokaryotes, 3rd edn, vol. 5, pp. 232-249. Edited by M. Dworkin, S. Falkow, E. Rosenberg, K. H. Schleifer \& E. Stackebrandt. New York: Springer.

Khan, S. T., Takaichi, S. \& Harayama, S. (2008). Paracoccus marinus sp. nov., an adonixanthin diglucoside-producing bacterium isolated from coastal seawater in Tokyo Bay. Int J Syst Evol Microbiol 58, 383-386.

Kim, B.-Y., Weon, H.-Y., Yoo, S.-H., Kwon, S.-W., Cho, Y.-H., Stackebrandt, E. \& Go, S.-J. (2006). Paracoccus homiensis sp. nov., isolated from a sea-sand sample. Int J Syst Evol Microbiol 56, 23872390.

Komagata, K. \& Suzuki, K. (1987). Lipid and cell-wall analysis in bacterial systematics. Methods Microbiol 19, 161-207.

Lanyí, B. (1987). Classical and rapid identification methods for medically important bacteria. Methods Microbiol 19, 1-67.

Lee, J. H., Kim, Y. S., Choi, T.-J., Lee, W. J. \& Kim, Y. T. (2004). Paracoccus haeundaensis sp. nov., a Gram-negative, halophilic, astaxanthin-producing bacterium. Int J Syst Evol Microbiol 54, 1699-1702.

Lee, K.-B., Liu, C.-T., Anzai, Y., Kim, H., Aono, T. \& Oyaizu, H. (2005), The hierarchical system of the 'Alphaproteobacteria': description of
Hyphomonadaceae fam. nov., Xanthobacteraceae fam. nov. and Erythrobacteraceae fam. nov. Int J Syst Evol Microbiol 55, 1907-1919.

Leifson, E. (1963). Determination of carbohydrate metabolism of marine bacteria. J Bacteriol 85, 1183-1184.

Liu, Z.-P., Wang, B.-J., Liu, X.-Y., Dai, X., Liu, Y.-H. \& Liu, S.-J. (2008). Paracoccus halophilus sp. nov., isolated from marine sediment of the South China Sea, China, and emended description of genus Paracoccus Davis 1969. Int J Syst Evol Microbiol 58, 257-261.

Pukall, R., Laroche, M., Kroppenstedt, R. M., Schumann, P., Stackebrandt, E. \& Ulber, R. (2003). Paracoccus seriniphilus sp. nov., an L-serine-dehydratase-producing coccus isolated from the marine bryozoan Bugula plumose. Int J Syst Evol Microbiol 53, 443447

Roh, S. W., Nam, Y.-D., Chang, H.-W., Kim, K.-H., Kim, M.-S., Shin, K.-S., Yoon, J.-H., Oh, H.-M. \& Bae, J.-W. (2009). Paracoccus aestuarii sp. nov., isolated from tidal flat sediment. Int J Syst Evol Microbiol 59, 790794

Sasser, M. (1990). Identification of bacteria by gas chromatography of cellular fatty acids, MIDI Technical Note 101. Newark, DE: MIDI Inc.

Stackebrandt, E. \& Goebel, B. M. (1994). Taxonomic note: a place for DNA-DNA reassociation and $16 \mathrm{~S}$ rRNA sequence analysis in the present species definition in bacteriology. Int J Syst Bacteriol 44, 846849.

Staley, J. T. (1968). Prosthecomicrobium and Ancalomicrobium: new prosthecate freshwater bacteria. J Bacteriol 95, 1921-1942.

Tamaoka, J. \& Komagata, K. (1984). Determination of DNA base composition by reversed-phase high-performance liquid chromatography. FEMS Microbiol Lett 25, 125-128.

Wayne, L. G., Brenner, D. J., Colwell, R. R., Grimont, P. A. D., Kandler, O., Krichevsky, M. I., Moore, L. H., Moore, W. E. C., Murray, R. G. E. \& other authors (1987). International Committee on Systematic Bacteriology. Report of the ad hoc committee on reconciliation of approaches to bacterial systematics. Int J Syst Bacteriol 37, 463-464.

Yoon, J.-H., Kim, H., Kim, S.-B., Kim, H.-J., Kim, W. Y., Lee, S. T., Goodfellow, M. \& Park, Y.-H. (1996). Identification of Saccharomonospora strains by the use of genomic DNA fragments and rRNA gene probes. Int J Syst Bacteriol 46, 502-505.

Yoon, J.-H., Lee, S. T. \& Park, Y.-H. (1998). Inter- and intraspecific phylogenetic analysis of the genus Nocardioides and related taxa based on 16S rRNA gene sequences. Int J Syst Bacteriol 48, 187-194.

Yoon, J.-H., Kim, I.-G., Shin, D.-Y., Kang, K. H. \& Park, Y.-H. (2003). Microbulbifer salipaludis sp. nov., a moderate halophile isolated from a Korean salt marsh. Int J Syst Evol Microbiol 53, 53-57. 